AutORA: FERNANDA PICULO

Orientadora: Profa. Dra. Marilza

VIERA CUNHA RUDGE

Resumo de Tese
Autora: Vanessa de Oliveira Sousa ORIENTADOR: Prof. Dr. AdRIANO DiAS Co-orientadora: Profa. Dra. Angélica Mércia Pascon Barbosa

\title{
Effects of mild diabetes on extracellular matrix and urethral striated muscle of pregnant rats
}

\author{
Efeito do diabete moderado na matriz extracelular e no músculo \\ estriado uretral em ratas prenhes
}

Dissertação de Mestrado apresentada ao Departamento de Ginecologia, Obstetrícia e Mastologia da Faculdade de Medicina de Botucatu-UNESP, em 22 de fevereiro de 2013

INTRODUCTION: Diabetes mellitus during pregnancy is associated with high levels of urinary incontinence and pelvic floor muscle dysfunction. Mild diabetes can lead to changes in urethral striated muscle and extracellular matrix in pregnant rats considering both structures as a whole system responsible for urinary continence. METHODS: Ninety-two female Wistar rats were distributed in four experimental groups: virgin, pregnant, diabetic and diabetic pregnant. All experimental procedures were approved by the Ethics Committee on Animal Experiments of the Botucatu Medical School - UNESP (Protocol Number 846). Mild diabetes was induced at the first day of birth by subcutaneous administration of streptozotocin at a dose of $100 \mathrm{mg} / \mathrm{kg}$ body weight. In adult life, parental non-diabetic female rats were mated with non-diabetic males to obtain newborns. On day 21 of the pregnancy, the rats were lethally anesthetized and the urethra and vagina were extracted as a unit. Urethral and vaginal sections were cut and analyzed by a) cytochemical staining for extracellular matrix and muscle components; b) immunohistochemistry to identify fast and slow muscle fibers; and c) transmission electron microscopy for ultrastructural analysis of urethral striated muscle. RESULTS: In comparison to the three control groups, variations in the urethral striated muscle and extracellular matrix from diabetic pregnant rats were observed including: thinning, disorganization, atrophy, fibrosis, increased blood vessels, accumulation of subsarcolemmal and intermyofibrillar mitochondria, lipid droplets and glycogen granules associated with co-localization of fast and slow fibers and a steady decrease in the proportion of fast to slow fibers. CONCLUSIONS: Mild diabetes and pregnancy can lead to time-dependent disorder and tissue remodeling in which the urethral striated muscle and extracellular matrix has a fundamental function.

\section{Influência dos distúrbios hiperglicêmicos na função do assoalho pélvico na gestação}

Influence of pelvic floor function byperglycemic disorders in pregnancy

Resumo de Tese

Palavras-chave

Diabete

Gestação

Assoalho pélvico

Keywords

Diabetes

Pregnancy

Pelvic floor
Tese apresentada ao Programa de Pós-Graduação em Ginecologia, Obstetrícia e Mastologia, da Faculdade de Medicina de Botucatu - UNESP, para obtenção do título de Doutor, em 1 de março de 2013.

OBJETIVO: verificar a associação entre a ocorrência de IU e função muscular do AP com os distúrbios hiperglicêmicos gestacionais. MÉTODOS: o estudo foi desenvolvido no Ambulatório de Pré-Natal do Hospital das Clinicas da Faculdade de Medicina de Botucatu - FMB/UNESP e aprovado pelo Comitê de Ética em Pesquisa da Faculdade de Medicina de Botucatu (protocolo no. 426/08). As gestantes foram avaliadas pela palpação digital, perineometria e eletromiografia (EMG). No primeiro momento da avaliação (M1), entre a 24a e 32 $2^{\circ}$ semanas gestacionais, avaliamos 115 gestantes divididas em dois grupos, 82 gestantes normoglicêmicas (NG) e 33 hiperglicêmicas (HG), e no segundo momento (M2), entre a 34a e 38a semana gestacional, 38 e $28 \mathrm{NG}$ e HG, respectivamente, retornaram para continuar as avaliações. A análise estatística foi realizada com nível de significância de 5\%. RESULTADOS: as hiperglicêmicas apresentaram idade cronológica e gestacional mais avançadas, além de menor estatura. Houve diferença significativa na distribuição peso-altura entre os grupos no M1. Não houve diferença entre os grupos, no $M 2$ quanto à ocorrência de IU. Na análise intergrupos da palpação digital, observamos redução da força muscular, enquanto que algumas mantiveram ou aumentaram. Na comparação das avaliações com perineômetro e EMG, entre e intragrupos, não houve diferenças significativas. CONCLUSÃO: no presente trabalho, não houve diferença estatística entre os grupos NG e HG. 